\title{
Correction to: Use of an oxygen planar optode to assess the effect of high velocity microsprays on oxygen penetration in a human dental biofilms in-vitro
}

Yalda Khosravi ${ }^{1}$, Rala D. P. Kandukuri ${ }^{2}$ Sara R. Palmer ${ }^{3}$, Erin S. Gloag ${ }^{1}$, Sergey M. Borisov ${ }^{4}$, E. Michelle Starke ${ }^{5}$, Marilyn T. Ward ${ }^{5}$, Purnima Kumar ${ }^{3}$, Dirk de Beer ${ }^{2}$, Arjun Chennu ${ }^{2}$ and Paul Stoodley ${ }^{1,6,7^{*}}$

Correction to: BMC Oral Health 20, 230 (2020)

https://doi.org/10.1186/s12903-020-01217-0

After publication of the original article [1], the authors identified errors in the authors' names of Sara R. Palmer and Rala D.P. Kandukuri.

The incorrect authors' names are: Sara Palmer and Raja Durga Prasad Kandukuri.

The correct authors' names are: Sara R. Palmer and Rala D.P. Kandukuri

The author group has been updated above and the original article [1] has been corrected.

\footnotetext{
Author details

'Department of Microbial Infection and Immunity, Ohio State University, Columbus, USA. ${ }^{2}$ Max Planck Institute for Marine Microbiology, Bremen, Germany. ${ }^{3}$ College of Dentistry, The Ohio State University, Columbus, $\mathrm{OH}$, USA. ${ }^{4}$ Institute of Analytical Chemistry and Food Chemistry Graz University of Technology Stremayrgasse, Graz, Austria. ${ }^{5}$ Philips Oral Healthcare, Bothell, Washington 98021, USA. ${ }^{6}$ Department Orthopaedics, Ohio State University, Columbus, USA. ${ }^{7}$ National Centre for Advanced Tribology (nCATS),

Mechanical Engineering, University of Southampton, Southampton, UK.
}

Published online: 04 September 2020 biofilms in-vitro. BMC Oral Health. 2020;20:230. https://doi.org/10.1186/ s12903-020-01217-0.

\section{Reference \\ 1. Khosravi Y, et al. Use of an oxygen planar optode to assess the effect of high velocity microsprays on oxygen penetration in a human dental}

\footnotetext{
The original article can be found online at https://doi.org/10.1186/s12903020-01217-0

*Correspondence: paul.stoodley@osumc.edu

'Department of Microbial Infection and Immunity, Ohio State University,

Columbus, USA

${ }^{6}$ Department Orthopaedics, Ohio State University, Columbus, USA

Full list of author information is available at the end of the article
}

(C) The Author(s). 2020 Open Access This article is licensed under a Creative Commons Attribution 4.0 International License, which permits use, sharing, adaptation, distribution and reproduction in any medium or format, as long as you give appropriate credit to the original author(s) and the source, provide a link to the Creative Commons licence, and indicate if changes were made. The images or other third party material in this article are included in the article's Creative Commons licence, unless indicated otherwise in a credit line to the material. If material is not included in the article's Creative Commons licence and your intended use is not permitted by statutory regulation or exceeds the permitted use, you will need to obtain permission directly from the copyright holder. To view a copy of this licence, visit http://creativecommons.org/licenses/by/4.0/ The Creative Commons Public Domain Dedication waiver (http://creativecommons.org/publicdomain/zero/1.0/) applies to the data made available in this article, unless otherwise stated in a credit line to the data. 